\title{
THP-1 macrophages and SGBS adipocytes - a new human in vitro model system of inflamed adipose tissue
}

\section{Michaela Keuper ${ }^{1}$, Anna Dzyakanchuk ${ }^{2}$, Kurt E. Amrein ${ }^{2}$, Martin Wabitsch ${ }^{1}{ }^{*}$ and Pamela Fischer-Posovszky ${ }^{1}$}

1 Division of Pediatric Endocrinology and Diabetes, Department of Pediatrics and Adolescent Medicine, Ulm University, Ulm, Germany

${ }_{2}^{2}$ Pharmaceutical Research and Early Development, F. Hoffmann-La Roche Ltd., Basel, Switzerland

\section{Edited by:}

Kerry McInnes, University of

Edinburgh, UK

\section{Reviewed by:}

Mark Nixon, University of Edinburgh UK

Graeme Lancaster, Baker IDI Heart and Diabetes Institute, Australia

\section{*Correspondence:}

Martin Wabitsch, Division of Pediatric

Endocrinology and Diabetes,

Department of Pediatrics and

Adolescent Medicine, Ulm University,

Eythstr 24, 89075 Ulm, Germany.

e-mail:martin.wabitsch@

uniklinik-ulm.de

\begin{abstract}
Obesity is associated with an accumulation of macrophages in adipose tissue. This inflammation of adipose tissue is a key event in the pathogenesis of several obesity-related disorders, particularly insulin resistance. Here, we summarized existing model systems that mimic the situation of inflamed adipose tissue in vitro, most of them being murine. Importantly, we introduce our newly established human model system which combines the THP-1 monocytic cell line and the preadipocyte cell strain Simpson-Golabi-Behmel syndrome (SGBS). THP-1 cells, which originate from an acute monocytic leukemia, differentiate easily into macrophages in vitro. The human preadipocyte cell strain SGBS was recently introduced as a unique tool to study human fat cell functions. SGBS cells are characterized by a high capacity for adipogenic differentiation. SGBS adipocytes are capable of fat cell-specific metabolic functions such as insulin-stimulated glucose uptake, insulinstimulated de novo lipogenesis and $\beta$-adrenergic-stimulated lipolysis and they secrete typical adipokines including leptin, adiponectin, and RBP4. Applying either macrophageconditioned medium or a direct co-culture of macrophages and fat cells, our model system can be used to distinguish between paracrine and cell-contact dependent effects. In conclusion, we propose this model as a useful tool to study adipose inflammation in vitro. It represents an inexpensive, highly reproducible human system. The methods described here can be easily extended for usage of primary human macrophages and fat cells.
\end{abstract}

Keywords: adipose tissue inflammation, SGBS, macrophages, adipocytes

\section{INTRODUCTION}

Obesity is characterized by a state of chronic, low-grade inflammation (Hotamisligil, 2006) with features like an increased production of chemokines and inflammatory cytokines including tumor necrosis factor alpha (TNF $\alpha$ ), interleukin-6 (IL6), and monocyte chemoattractant protein-1 (MCP-1; Shoelson et al., 2006). Another feature is the activation of inflammatory signaling pathways including inhibitor of NF- $\mathrm{KB}$ kinase beta (IKK- $\beta$ ) and c-Jun NH2-terminal kinase (JNK; Yuan et al., 2001; Hirosumi et al., 2002). The leading role for these inflammatory pathways in the development of obesity-associated insulin resistance was demonstrated by several loss of function studies (Arkan et al., 2005; Solinas et al., 2007).

It is evident that macrophages infiltrate human and murine adipose tissue with increasing body weight (Weisberg et al., 2003; Xu et al., 2003). Nevertheless, the pathogenic mechanisms leading to macrophage accumulation in the obese state are still not completely understood. Several hypotheses arose during the last decade. Local hypoxia (Hosogai et al., 2007; Halberg et al., 2009), fat cell apoptosis (Fischer-Posovszky et al., 2011) as well as adipocyte hypertrophy, oxidative stress, or endoplasmic reticulum stress (Furukawa et al., 2004; Ozcan et al., 2004; Gregor and Hotamisligil, 2007; Skurk et al., 2007; Wood et al., 2009) might trigger macrophage infiltration into obese adipose tissue.
Adipose tissue macrophages secrete inflammatory cytokines thereby inducing local and systemic inflammation. Furthermore, they stimulate expression and secretion of inflammatory cytokines in fat cells. Therefore, adipocytes themselves, in addition to macrophages, are involved in obesity-induced inflammation and insulin resistance.

Understanding how adipocytes and macrophages interact on a cellular and molecular level will contribute to shed light on adipose tissue inflammation. Furthermore, it will extend the knowledge about insulin resistance in adipocytes and might help to uncover new pharmacological targets for treatment options. For this purpose, cell culture techniques offer almost unlimited possibilities and help to gain first insights into interaction and underlying molecular mechanisms. Moreover, they may be perfectly suited to highlight species differences observed between rodents and man. This review shortly summarizes existing in vitro model systems for the inflamed adipose tissue, most of them being murine, and introduces a new human model system, i.e., THP-1 macrophages and the unique Simpson-Golabi-Behmel syndrome (SGBS) cell strain.

\section{THE PAST - SUMMARY OF EXISTING MODEL SYSTEMS}

The first studies which investigated the effects of macrophagesecreted factors on adipocyte biology were carried out in the 1980s (Pekala et al., 1983). Back then Pekala et al. (1983) used 
conditioned media from macrophages to stimulate murine 3T3L1 cells. Despite its simplicity this powerful and useful cell culture tool was almost forgotten. In the last decade, however, it became clear that the obesity-associated macrophage infiltration into adipose tissue contributes to obesity-associated health risks especially insulin resistance. This new perspective stimulated studies on the biological interaction of adipocytes and macrophages. Several research groups rediscovered "the old" experimental setup and found it very useful to study adipose tissue inflammation in vitro. A summary of typically used combinations of cellular models is given in Table 1.

3T3-L1 adipocytes and murine macrophages such as RAW264 or J774 are the most commonly used combinations. Several studies provided important insights on how macrophages or macrophagesecreted factors induce insulin resistance in adipocytes on a cellular level (Constant et al., 2006; Permana et al., 2006). In addition, these systems helped to identify signaling pathways contributing to the development of insulin resistance (Lumeng et al., 2007b; Constant et al., 2008). However, murine 3T3-L1 adipocytes are aneuploid (Gregoire et al., 1998) and behave different than human adipocytes in some regards. For instance, murine 3T3L1 cells and human SGBS cells show different sensitivity toward

Table 1 | In vitro models (conditioned media, indirect, or direct co-cultures) for studying the inflammatory process in adipose tissue.

\begin{tabular}{|c|c|c|c|c|}
\hline \multicolumn{2}{|c|}{ Adipocyte model } & \multicolumn{2}{|c|}{ Macrophage model } & \multirow{2}{*}{$\begin{array}{l}\text { Reference } \\
\text { Lumeng et al. (2007b), Mol- } \\
\text { gat et al. (2009), Hirai et al. } \\
(2010)\end{array}$} \\
\hline Murine & 3Т3-L1 & Murine & RAW264 & \\
\hline Murine & 3T3-L1 & Murine & J774.A1 & $\begin{array}{l}\text { Yarmo et al. (2009), Lu et al. } \\
\text { (2010), Ide et al. (2011), Mol- } \\
\text { gat et al. (2011) }\end{array}$ \\
\hline Murine & 3Т3-L1 & Murine & C2D & Xie et al. (2010) \\
\hline Murine & 3Т3-L1 & Murine & Primary & $\begin{array}{l}\text { Hirasaka et al. (2007), Sug- } \\
\text { anami et al. (2007a), Toyoda } \\
\text { et al. (2008), Kennedy et al. } \\
\text { (2011) }\end{array}$ \\
\hline Murine & 3Т3-L1 & Human & THP-1 & $\begin{array}{l}\text { Unoki et al. (2008), Con- } \\
\text { stant et al. (2008) }\end{array}$ \\
\hline Murine & 3T3-F442A & Murine & RAW264 & Tanaka et al. (2009) \\
\hline Murine & OP9 & Human & U937 & Xiao et al. (2010) \\
\hline Murine & Primary & Murine & RAW264 & $\begin{array}{l}\text { Sakurai et al. (2010), Chang } \\
\text { et al. (2011) }\end{array}$ \\
\hline Human & Primary & Human & THP-1 & $\begin{array}{l}\text { Constant et al. (2006), Bas- } \\
\text { sols et al. (2009), Bouw- } \\
\text { man et al. (2009), Gao } \\
\text { et al. (2010), Miranville et al. } \\
\text { (2010), Yarmo et al. (2010) }\end{array}$ \\
\hline Human & Primary & Human & U937 & $\begin{array}{l}\text { Bumrungpert et al. (2010), } \\
\text { Overman et al. (2010), } \\
\text { Samuvel et al. (2010) }\end{array}$ \\
\hline Human & Primary & Human & Primary & $\begin{array}{l}\text { Lacasa et al. (2007), } \\
\text { Keophiphath et al. (2009), } \\
\text { Chazenbalk et al. (2011) }\end{array}$ \\
\hline
\end{tabular}

apoptosis induction. While 3T3-L1 preadipocytes and adipocytes are sensitive to apoptosis induction by serum deprivation (Magun et al., 1998), human SGBS preadipocytes and adipocytes and also human primary adipocytes are characterized by a general resistance to apoptosis stimuli including serum withdrawal (FischerPosovszky et al., 2004). While macrophage-conditioned media stimulated Akt phosphorylation in 3T3-L1 cells (Molgat et al., 2011), Akt phosphorylation was inhibited in our human model system (Keuper et al., 2011) further supporting the differences between murine and human cells.

Additionally, murine and human macrophages display differences (Mestas and Hughes, 2004). In particular, expression of surface molecules is slightly different. In contrast to humans, murine adipose tissue macrophages are characterized by a low CD14 expression (Lumeng et al., 2007a). Furthermore, there has been considerable controversy as to whether human macrophages express inducible NO synthase (iNOS; Schneemann and Schoedon, 2002). Studies suggest different iNOS activity in macrophage populations in murine versus human models of inflammation (Zhang et al., 1996; Schneemann and Schoedon, 2002; Lumeng et al., 2007a).

Experimental alternatives are scarce when it comes to human physiology. Some groups used human primary adipocytes in combination with human macrophage cell lines or primary macrophages. This approach has the advantage of being very close to human physiology and helps to identify inter-individual variations. On the other hand, the usage of human primary material has several limitations. Availability of tissue samples is restricted and related to ethical issues. Techniques for the preparation of human preadipocytes/adipocytes are sophisticated and time-consuming. As a consequence, these cells are expensive when obtained from a commercial source. Fat cells ex vivo have a limited survival time, and preadipocytes loose their capacity for adipogenic differentiation after only a few passages in vitro. Inter-individual differences might also be prejudicial for some applications, where a high reproducibility of results is indispensable. Especially when needed for instance for large-scale drug testing, human primary preadipocytes or adipocytes no longer provide a useful model system.

Therefore we aimed at developing a model system of inflamed adipose tissue using a human preadipocyte cell strain assuring sufficient starting material, easy handling, and high reproducibility.

In 2001 we introduced the human SGBS cell strain, which is characterized by a high capacity for in vitro differentiation (Wabitsch et al., 2001). SGBS preadipocytes are cultured in DMEM/Ham's F12 (1:1) containing $33 \mu \mathrm{M}$ biotin, $17 \mu \mathrm{M}$ pantothenate, antibiotics (serum-free, basal medium), and 10\% FCS and adipogenic differentiation is induced after reaching near confluence as described previously (Fischer-Posovszky et al., 2006). Up till generation 50 the cells retain their ability for adipogenic differentiation. Additionally, once they are differentiated they function and behave as primary isolated human fat cells. They show a typical fat cell-specific metabolism including insulin-stimulated glucose uptake, and de novo lipogenesis (Fischer-Posovszky et al., 2008). Furthermore, $\beta$-adrenergic stimuli activate lipolysis and SGBS adipocytes express and secrete adipokines including leptin, adiponectin, and RBP4 (Fischer-Posovszky et al., 2008). 


\section{SOME STUDIES ON HUMAN INFLAMED ADIPOSE TISSUE USING SGBS CELLS}

Since the first publication, SGBS cells have been spread to several laboratories all over the world. Many successfully published studies demonstrate the power and utility of the SGBS cell strain. It provides an almost unlimited source of homogeneous human preadipocytes with high differentiation capacity (FischerPosovszky et al., 2008). SGBS cells are broadly used to study adipogenic differentiation or effects of drugs and food compounds on fat cell function. However, few studies have focused on inflammation.

Permana et al. (2009) used SGBS adipocytes in combination with human U937 cells. The U937 cell line represents a well characterized model for human macrophages. Expression and secretion of inflammatory cytokines were highly increased and adiponectin expression and secretion was reduced, when SGBS cells were treated with U937-macrophage-conditioned medium (MacCM; Permana et al., 2009). Additionally, they showed an increased lipolytic activity of adipocytes after exposure to macrophagesecreted factors (Permana et al., 2009). Lipolysis might locally aggravate the pro-inflammatory process by releasing FFA which in turn exert pro-inflammatory effects on macrophages and adipocytes (Suganami et al., 2007b). These adverse effects of macrophage-secreted factors on fat cells were ameliorated or even diminished by treatment with pioglitazone, an insulin-sensitizing thiazolidinedione (Permana et al., 2009). SGBS cells in combination with U937-MacCM were also used to perform microarray analysis (O'Hara et al., 2009). About 1088 transcripts were up- or down-regulated by treatment with macrophage-secreted factors and the authors validated selected genes by real-time PCR (O'Hara et al., 2009). Several matrix metalloproteinase were up-regulated including MMP1, MMP3, MMP9, MMP10, MMP12, and MMP19 and also accumulated in the medium supernatants. The authors concluded from this study that macrophages contribute to tissue remodeling processes in obese adipose tissue (O'Hara et al., 2009).

Another possibility is the usage of human primary macrophages isolated from blood. Even more elegantly, Wentworth et al. (2010) isolated macrophages from human adipose tissue samples. They performed collagenase digestion to isolate stromal vascular cells from adipose tissue and then used a flow cytometry cell sorting strategy to collect $\mathrm{CD} 11^{+}$-macrophages. The ex vivo culture of human adipose tissue macrophages is certainly very close to human physiology and well suited to identify patientspecific characteristics. Using this strategy, the authors found that only $\mathrm{CD} 11 \mathrm{c}^{+}$-macrophages and not $\mathrm{CD} 11 \mathrm{c}^{-}$-macrophages induce insulin resistance in SGBS fat cells (Wentworth et al., 2010).

Overnutrition and hypoxia were discussed as factors initiating macrophage infiltration into adipose tissue in the obese state (Trayhurn and Wood, 2004; Hosogai et al., 2007). Both processes were studied in the SGBS cell system. High doses of glucose or saturated fatty acids were reported to induce expression of chemoattractants like serum amyloid A (SAA) or MCP-1 (Yeop Han et al., 2010). Hypoxia led to robust changes in mRNA expression in SGBS adipocytes (Geiger et al., 2011).
THE PRESENT - ESTABLISHING A HUMAN SYSTEM WITH HIGH REPRODUCIBILITY AND ALMOST UNLIMITED AVAILABILITY

\section{EXPERIMENTAL SETUP FOR A HUMAN IN VITRO MODEL SYSTEM OF INFLAMED ADIPOSE TISSUE}

We tested three different, human monocytic cell lines (U937, MonoMac6, THP-1). The THP-1 cell line was most suitable due to easy handling and a macrophage-like phenotype after in vitro differentiation presumably very similar to human adipose tissue macrophages in vivo. THP-1 is a well described cell line and commonly used as a model for human macrophages (Tsuchiya et al., 1980). THP-1 cells are cultured in RPMI containing $100 \mu \mathrm{M}$ nonessential amino acids, $2 \mathrm{mM} \mathrm{L}$-glutamine, $1 \mathrm{mM}$ sodium pyruvate, antibiotics (basal medium), and 10\% FCS. We induced differentiation of THP-1 cells into macrophages by incubation with $125 \mathrm{ng} / \mathrm{ml}$ phorbol myristate acetate (PMA) for $48 \mathrm{~h}$ in serumfree basal medium. We characterized the differentiation process in extenso. For example, the expression of macrophage-specific surface molecules such as CD11c, CD54, CD86 as well as production and secretion of inflammatory cytokines is dramatically increased after differentiation into macrophages (Tsuchiya et al., 1982; Keuper et al., 2011). Most conveniently, the differentiation from monocytes to macrophages goes along with a marked change in morphology. While THP-1 monocytes grow in suspension, THP-1 macrophages adhere to the culture dishes and remain adherent. Thus, the differentiation process can be easily controlled and monitored.

Combining SGBS cells with THP-1 cells creates a perfect human model system with unlimited availability. Both cell types can be used as precursors (monocytes, preadipocytes) or differentiated into their final phenotype (macrophages, adipocytes; Figure 1A). This system can be used to study endocrine effects by using just the conditioned medium or a transwell co-culture system. Cellular interactions can be monitored by a direct co-culture system (Figure 1B). For the use of conditioned media, in vitro differentiated THP-1 cells $\left(10^{6} / \mathrm{ml}\right)$ were incubated with serum-free basal medium to achieve chemically well-defined conditions. In addition, $0.5 \%$ bovine serum albumin (BSA) is added to stabilize macrophage-secreted factors. Macrophage-conditioned media (MacCM) were collected after $48 \mathrm{~h}$ and cleared by centrifugation. For a direct co-culture system, THP-1 macrophages were added directly to cultures of SGBS cells at increasing rates (THP-1:SGBS $1: 10,1: 2,1: 1,2: 1)$. SGBS cells and THP-1 cells show optimal growth in distinct cell culture media (THP-1: RPMI, SGBS: DMEM-F12). To exclude effects caused by the cell culture medium, we used serum-free THP-1 medium containing $0.5 \%$ BSA in corresponding concentrations as vehicle control for the cell-free as well as the direct co-culture system.

\section{FUNCTIONAL CHARACTERIZATION OF THE MODEL SYSTEM}

Adipose tissue inflammation is one of the key elements in the pathogenesis of obesity-related insulin resistance. This has been shown by several animal and human studies including in vivo and in vitro investigations (Yuan et al., 2001; Hirosumi et al., 2002; Arkan et al., 2005; Solinas et al., 2007). Macrophages or macrophage-secreted factors inhibit several insulin-stimulated 


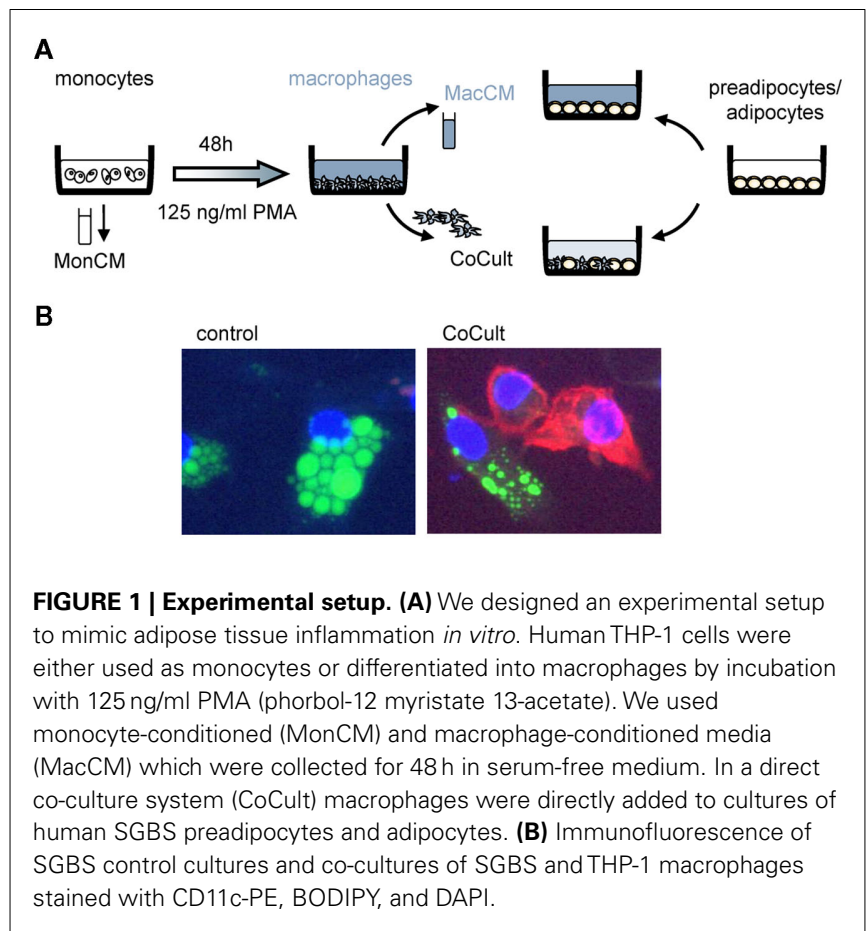

processes of preadipocytes and adipocytes. The inhibition of adipogenic differentiation was demonstrated in the above mentioned murine model system as well as in primary isolated preadipocytes (Constant et al., 2006; Yarmo et al., 2010). As this effect was well characterized, we used it as a positive control for the initial characterization of our SGBS/THP-1 system. We differentiated SGBS cells for 10 days in the presence of MacCM or vehicle. Fresh MacCM was added to the differentiation medium with each medium change. Analyzing the lipid content of the resulting cell cultures, we found a complete inhibition of adipogenic differentiation as judged morphologically by the absence of intracellular lipid droplets (Figure 2A). A Nile Red staining confirmed this finding (Figure 2B). In parallel, the expression of the adipocyte marker gene PPAR $\gamma$ was diminished as assessed by quantitative real-time PCR (Figure 2C). For the co-culture system, in vitro differentiated THP-1 macrophages supplied in adipogenic differentiation medium were added directly to cultures of SGBS cells. In line with findings from MacCM, the direct co-culture system resulted in a dose-dependent inhibition of the adipogenic differentiation process (Figures 2D,E) The ratio of one macrophage to 10 SGBS cells is well achievable in the in vivo situation. Around 10\% macrophages were detected in human adipose tissue samples of obese subjects by immunohistochemistry (Harman-Boehm et al., 2007). Notably, macrophages accumulate around dead, apoptotic fat cells suggesting a locally increased macrophage:fat cell ratio (Cinti et al., 2005; Alkhouri et al., 2010; Keuper et al., 2011).

Also other insulin-dependent functions of the fat cell were characterized. As such, we showed in a previously published paper that macrophage-secreted factors inhibit insulin-stimulated glucose uptake by 65\% (Keuper et al., 2011). Likewise, the de novo generation of triglycerides from glucose was decreased by 4.5 -fold in the presence of macrophage-secreted factors. On the molecular

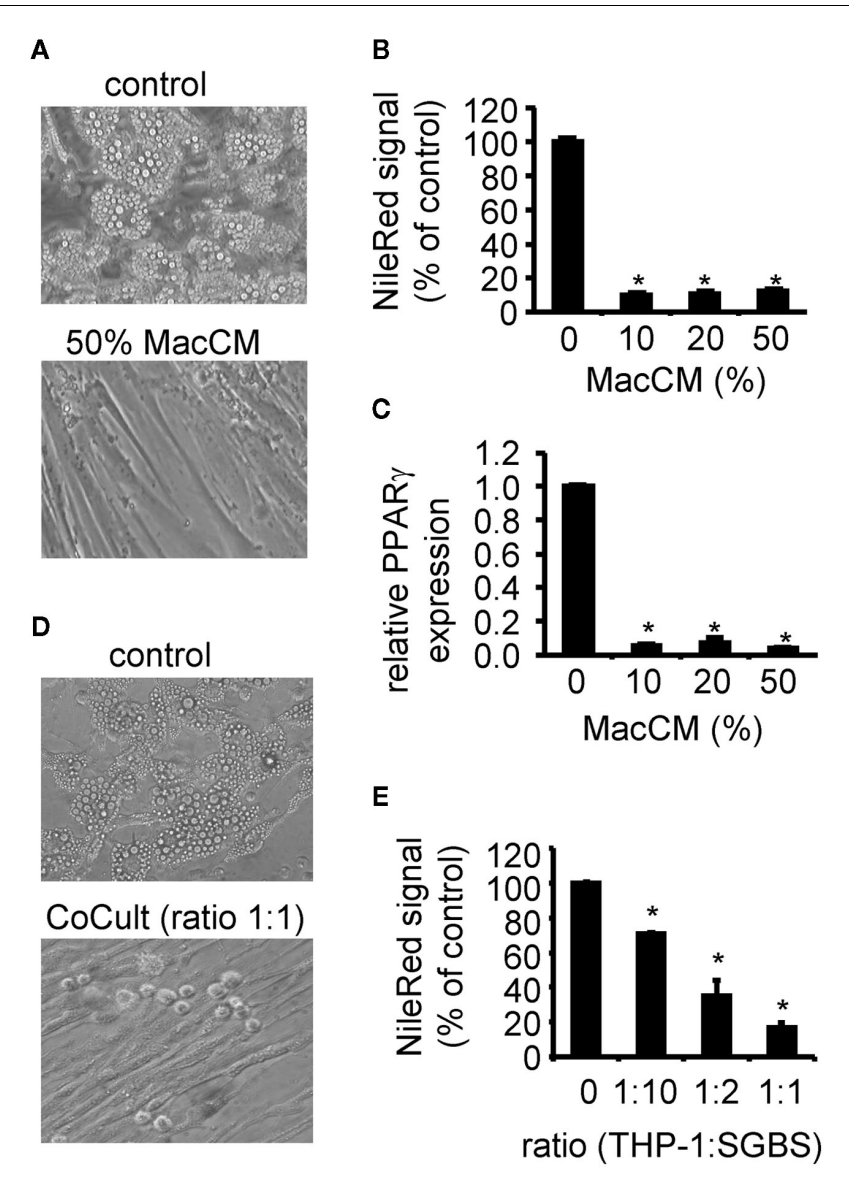

FIGURE 2 | Effect of macrophage-conditioned medium (MacCM) and co-culture on adipogenic differentiation. (A) SGBS preadipocytes were incubated with $\operatorname{MacCM}(10,20,50 \%)$ or vehicle during adipogenic differentiation. At day 10 cells were analyzed. (B) Lipid accumulation was assessed by staining the cells with the lipophilic dye Nile Red. (C) mRNA expression of PPAR $\gamma$ was analyzed by qPCR and normalized to succinate dehydrogenase complex subunit A (SDHA) and related to control using the $\Delta \Delta$ Ct method. (D) In vitro differentiated THP-1 macrophages were added to cultures of SGBS preadipocytes at increasing rates (THP-1:SGBS 1:10, $1: 2,1: 1)$ during adipogenic differentiation. (E) Lipid accumulation was assessed by staining the cells with Nile Red. Nile Red signals of macrophage cultures were subtracted as background. Data are presented as mean + SEM of three independent experiments. ${ }^{*} p<0.05$.

level, macrophage-secreted factors caused a decrease in Akt phosphorylation, one of the key players in insulin signal transduction (Keuper et al., 2011).

Taken together, our human model system of inflamed adipose tissue showed the expected characteristics in terms of insulin sensitivity, i.e., an inhibition of adipogenic differentiation, a decrease in glucose uptake and lipogenesis and reduced phosphorylation of Akt.

Furthermore, the inflammatory micro-environment mimicked by MacCM induced a shift toward a pro-inflammatory adipocyte secretion profile. SGBS adipocytes were treated with MacCM or vehicle. After $24 \mathrm{~h}$ total mRNA was prepared and the expression of several target genes was analyzed by qPCR. The mRNA expression of adiponectin expression was robustly reduced (Figure $\mathbf{3 A}$ ), while 
A

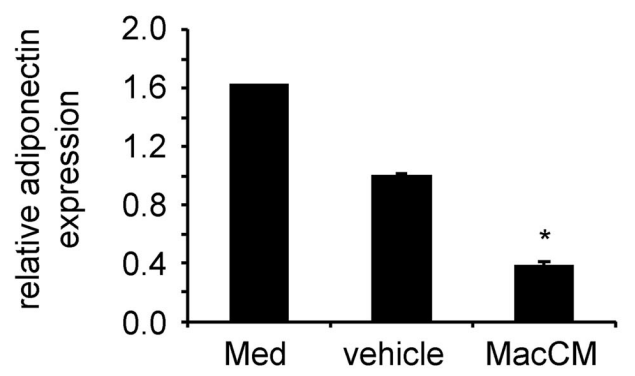

B

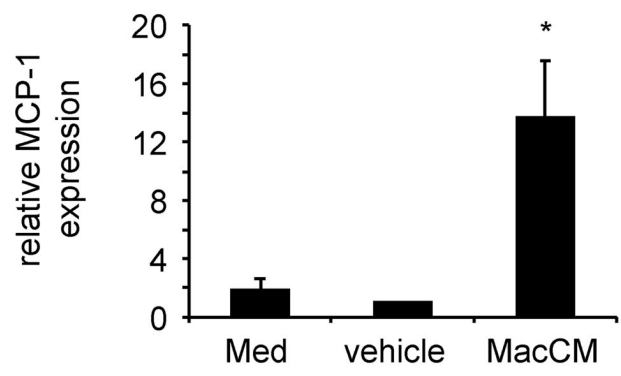

C

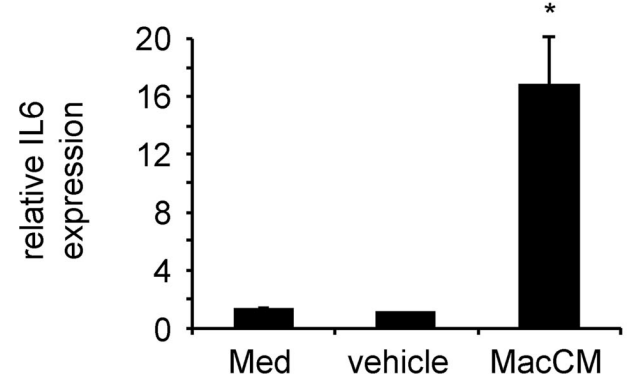

D

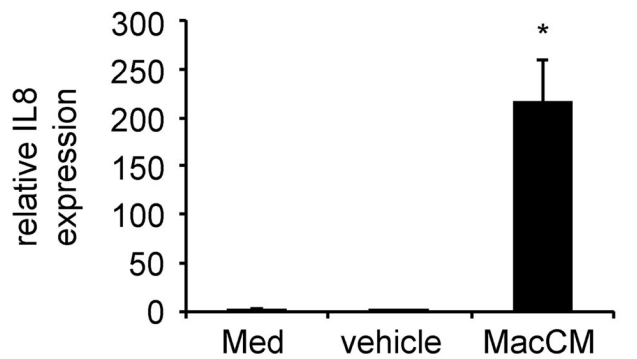

E

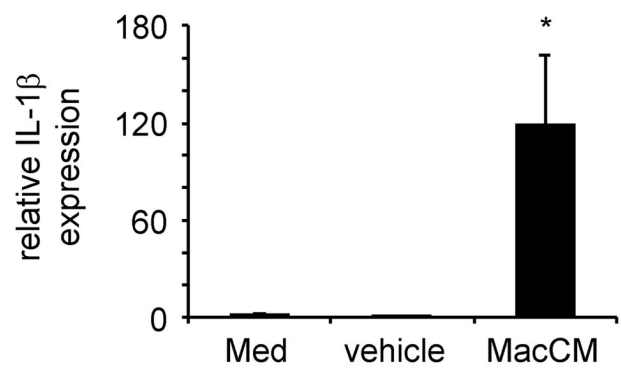

FIGURE 3 | Macrophage-conditioned medium (MacCM) differentially regulates adipokine expression. SGBS adipocytes were incubated with medium, vehicle control, or 50\% MacCM. After $24 \mathrm{~h}$ total RNA was prepared and reversely transcribed. Expression of adiponectin (A), monocyte chemoattractant protein-1 (MCP-1) (B), interleukin-6 (IL6) (C), interleukin-8 (IL8) (D), and interleukin-1 beta (IL1 $\beta$ ) (E) was analyzed by qPCR. The mRNA levels of target genes were normalized to those of succinate dehydrogenase complex subunit $\mathrm{A}$ (SDHA) using the $\triangle \mathrm{Ct}$ method and related to vehicle control using $\Delta \Delta \mathrm{Ct}$ method. Data are presented as mean + SEM of three independent experiments. ${ }^{*} p<0.05$. production of inflammatory chemokines and cytokines including MCP-1 (Figure 3B), interleukin-6 (IL6; Figure 3C), interleukin8 (IL8; Figure 3D), and interleukin-1beta (IL1 $\beta$; Figure 3E) was strongly increased.

\section{THE FUTURE - POSSIBILITIES TO EXPAND AND USE THE NEW HUMAN IN VITRO SYSTEM}

Our model system of human adipose tissue inflammation has been well characterized, but future efforts will help to further improve it. For example, cells lines could be replaced by primary cells if the identification of variations between patients is the main goal. As mentioned above SGBS cells were already successfully combined with primary isolated macrophages (Wentworth et al., 2010).

Additionally, model system like ours could be expanded with other important cell types found in obese adipose tissue. Interestingly, a close connection of $\mathrm{T}$ cells and the inflammatory process was reported. $\mathrm{CD} 11 \mathrm{c}^{+}$cells are responsible for the $\mathrm{T}$ cell infiltration and activation (Wu et al., 2007). The $\mathrm{CD}^{+} \mathrm{T}$ cell infiltration is linked to insulin resistance and obesity-associated inflammation (Kintscher et al., 2008; Nishimura et al., 2009). Recently, an important role for $\mathrm{CD} 4^{+} \mathrm{T}$ cells in the regulation of body weight, glucose tolerance, and insulin resistance was added to this picture (Winer et al., 2009). Since these studies implicate an important role for $\mathrm{T}$ cells in disease progression during diet-induced obesity, adding this cell type to our model might further enhance the system and the knowledge about their cellular and molecular interactions. Studies of murine $\mathrm{CD}^{+} \mathrm{T}$ cells in co-culture with adipocytes and macrophages showed an important role for $\mathrm{CD}^{+}$ $\mathrm{T}$ cells in macrophage differentiation, migration, and activation (Nishimura et al., 2009). However, since we observed crucial differences between murine and human adipocytes this interplay has to be verified in a human model system.

Obesity is associated with endothelial dysfunction, a key early event in the initiation and progression of atherosclerosis (Steinberg et al., 1996). Endothelial dysfunction accompanies many of the obesity-associated disorders and is a predictor of future adverse cardiovascular events (Williams et al., 2005). Furthermore obesity is associated with dysregulated angiogenesis within the expanding adipose tissue (Halberg et al., 2009) suggesting a critical role for endothelial cells in this context. Endothelial cells isolated from human adipose tissue stimulate preadipocyte proliferation (Hutley et al., 2001). By incorporating endothelial cells into our system, interactions between human adipocytes and endothelial cells could be further elucidated and investigated in an inflammatory environment.

Importantly, SGBS adipocytes are suitable for culture in 96well plates as well as 384-well plates allowing large-scale drug testing. As such, the SGBS:THP-1 co-culture system was successfully applied to study the effects of aleglitazar in a context of inflamed adipose tissue (Dzyakanchuk et al., 2010). Aleglitazar is a balanced dual peroxisome proliferator-activated receptor (PPAR) alpha/gamma agonist, designed to optimize lipid and glycemic benefits (Dzyakanchuk et al., 2010).

\section{CONCLUSION}

Taken together, our data suggest that THP-1 macrophages are able to create an inflammatory micro-environment very similar to the one found in vivo. SGBS adipocytes develop a phenotype 
of insulin resistance and their secretion profile undergoes a proinflammatory shift when exposed to this inflammatory environment. Therefore, we propose that this model system represents an excellent and easy-to-use opportunity to study molecular as well as cellular changes and effects in adipocytes in the context of an inflamed adipose tissue. Notably, this system also allows large-scale drug screening which might be very useful to find new compounds that ameliorate adipose tissue inflammation and/or restore normal adipocyte function despite inflammation.

\section{REFERENCES}

Alkhouri, N., Gornicka, A., Berk, M. P., Thapaliya, S., Dixon, L. J., Kashyap, S., Schauer, P. R., and Feldstein, A. E. (2010). Adipocyte apoptosis, a link between obesity, insulin resistance, and hepatic steatosis. J. Biol. Chem. 285, 3428-3438.

Arkan, M. C., Hevener, A. L., Greten, F. R., Maeda, S., Li, Z.-W., Long, J. M., Wynshaw-Boris, A., Poli, G., Olefsky, J., and Karin, M. (2005). IKKbeta links inflammation to obesityinduced insulin resistance. Nat. Med. 11, 191-198.

Bassols, J., Ortega, F. J., MorenoNavarrete, J. M., Peral, B., Ricart, W., and Fernández-Real, J.-M. (2009). Study of the proinflammatory role of human differentiated omental adipocytes. J. Cell. Biochem. 107, 1107-1117.

Bouwman, J. J. M., Diepersloot, R. J. A., and Visseren, F. L. J. (2009). Intracellular infections enhance interleukin-6 and plasminogen activator inhibitor 1 production by cocultivated human adipocytes and THP-1 monocytes. Clin. Vaccine Immunol. 16, 1222-1227.

Bumrungpert, A., Kalpravidh, R. W., Chuang, C.-C., Overman, A., Martinez, K., Kennedy, A., and McIntosh, M. (2010). Xanthones from mangosteen inhibit inflammation in human macrophages and in human adipocytes exposed to macrophageconditioned media. J. Nutr. 140, 842-847.

Chang, H.-P., Wang, M.-L., Hsu, C.-Y., Liu, M.-E., Chan, M.-H., and Chen, Y.-H. (2011). Suppression of inflammation-associated factors by indole-3-carbinol in mice fed highfat diets and in isolated, co-cultured macrophages and adipocytes. Int. J. Obes. (Lond.). Available at: http:// www.ncbi.nlm.nih.gov/pubmed/21 343904 (accessed March 16, 2011).

Chazenbalk, G., Bertolotto, C., Heneidi, S., Jumabay, M., Trivax, B., Aronowitz, J., Yoshimura, K., Simmons, C. F., Dumesic, D. A., and Azziz, R. (2011). Novel pathway of adipogenesis through cross-talk between adipose tissue macrophages, adipose stem cells plasticity. PLoS ONE 6, e17834. doi:10.1371/journal.pone.0017834

Cinti, S., Mitchell, G., Barbatelli, G., Murano, I., Ceresi, E., Faloia, E., Wang, S., Fortier, M., Greenberg, A. S., and Obin, M. S. (2005). Adipocyte death defines macrophage localization and function in adipose tissue of obese mice and humans. J. Lipid Res. 46, 2347-2355.

Constant, V. A., Gagnon, A., Landry, A., and Sorisky, A. (2006). Macrophageconditioned medium inhibits the differentiation of 3T3-L1 and human abdominal preadipocytes. Diabetologia 49, 1402-1411.

Constant, V. A., Gagnon, A., Yarmo, M., and Sorisky, A. (2008). The antiadipogenic effect of macrophageconditioned medium depends on ERK1/2 activation. Metab. Clin. Exp. 57, 465-472.

Dzyakanchuk, A., Wright, M. B., Sebokova, E., Wabitsch, M., FischerPosovszky, P., Keuper, M., and Amrein, K. (2010). Abstract 10854: aleglitazar, a balanced dual ppar alpha/gamma agonist, decreases lipolysis and cytokine production in a cellular model of inflamed human adipose tissue. Circulation 122, A10854.

Fischer-Posovszky, P., Hebestreit, H., Hofmann, A. K., Strauss, G., Moller, P., Debatin, K. M., and Wabitsch, M. (2006). Role of CD95-mediated adipocyte loss in autoimmune lipodystrophy. J. Clin. Endocrinol. Metab. 91, 1129-1135.

Fischer-Posovszky, P., Newell, F. S., Wabitsch, M., and Tornqvist, $\mathrm{H}$. E. (2008). Human SGBS cells - a unique tool for studies of human fat cell biology. Obes. Facts 1, 184-189.

Fischer-Posovszky, P., Tornqvist, H., Debatin, K. M., and Wabitsch, M. (2004). Inhibition of death-receptor mediated apoptosis in human adipocytes by the insulin-like growth factor I (IGF-I)/IGF-I receptor autocrine circuit. Endocrinology 145, 1849-1859.

Fischer-Posovszky, P., Wang, Q. A., Asterholm, I. W., Rutkowski, J. M., and adipocytes: evidence of cell

\section{ACKNOWLEDGMENTS}

We gratefully acknowledge Alexandra Killian for excellent technical assistance. Pamela Fischer-Posovszky is funded by a Margarete von Wrangell scholarship financed by the Baden-Wuerttemberg Ministry of Science, Research and Arts, the European Social Fund, and Ulm University.

This work has been supported within the Programme 'Metabolic Disorders' by the Ministry for Research of the state BadenWürttemberg.

and Scherer, P. E. (2011). Targeted deletion of adipocytes by apoptosis leads to adipose tissue recruitment of alternatively activated M2 macrophages. Endocrinology 152, 3074-3081.

Furukawa, S., Fujita, T., Shimabukuro, M., Iwaki, M., Yamada, Y., Nakajima, Y., Nakayama, O., Makishima, M., Matsuda, M., and Shimomura, I. (2004). Increased oxidative stress in obesity and its impact on metabolic syndrome. J. Clin. Invest. 114 1752-1761.

Gao, D., Trayhurn, P., and Bing, C. (2010). Macrophage-secreted factors inhibit ZAG expression and secretion by human adipocytes. Mol. Cell. Endocrinol. 325, 135-142.

Geiger, K., Leiherer, A., Muendlein, A. Stark, N., Geller-Rhomberg, S., Saely, C. H., Wabitsch, M., Fraunberger, P., and Drexel, H. (2011). Identification of hypoxia-induced genes in human SGBS adipocytes by microarray analysis. PLOS ONE 6, e26465. doi:10.1371/journal.pone.0026465

Gregoire, F. M., Smas, C. M., and Sul, H. S. (1998). Understanding adipocyte differentiation. Physiol. Rev. 78, 783-809.

Gregor, M. F., and Hotamisligil, G. S. (2007). Thematic review series: adipocyte biology. Adipocyte stress: the endoplasmic reticulum and metabolic disease. J. Lipid Res. 48, 1905-1914.

Halberg, N., Khan, T., Trujillo, M. E., Wernstedt-Asterholm, I., Attie, A. D., Sherwani, S., Wang, Z. V., Landskroner-Eiger, S., Dineen, S., Magalang, U. J., Brekken, R. A., and Scherer, P. E. (2009). Hypoxiainducible factor lalpha induces fibrosis and insulin resistance in white adipose tissue. Mol. Cell. Biol. 29, 4467-4483.

Harman-Boehm, I., Blüher, M., Redel, H., Sion-Vardy, N., Ovadia, S., Avinoach, E., Shai, I., Klöting, N., Stumvoll, M., Bashan, N., and Rudich, A. (2007). Macrophage infiltration into omental versus subcutaneous fat across different populations: effect of regional adiposity and the comorbidities of obesity. J. Clin. Endocrinol. Metab. 92, 2240-2247.

Hirai, S., Uemura, T., Mizoguchi, N., Lee, J.-Y., Taketani, K., Nakano, Y., Hoshino, S., Tsuge, N., Narukami, T., Yu, R., Takahashi, N., and Kawada, T. (2010). Diosgenin attenuates inflammatory changes in the interaction between adipocytes and macrophages. Mol. Nutr. Food Res. 54, 797-804.

Hirasaka, K., Kohno, S., Goto, J., Furochi, H., Mawatari, K., Harada, N., Hosaka, T., Nakaya, Y., Ishidoh, K., Obata, T., Ebina, Y., Gu, H., Takeda, S., Kishi, K., and Nikawa, T. (2007). Deficiency of Cbl-b gene enhances infiltration and activation of macrophages in adipose tissue and causes peripheral insulin resistance in mice. Diabetes 56, 2511-2522.

Hirosumi, J., Tuncman, G., Chang, L., Görgün, C. Z., Uysal, K T., Maeda, K., Karin, M., and Hotamisligil, G. S. (2002). A central role for JNK in obesity and insulin resistance. Nature 420, 333-336.

Hosogai, N., Fukuhara, A., Oshima, K., Miyata, Y., Tanaka, S., Segawa, K., Furukawa, S., Tochino, Y., Komuro, R., Matsuda, M., and Shimomura, I. (2007). Adipose tissue hypoxia in obesity and its impact on adipocytokine dysregulation. Diabetes 56, 901-911.

Hotamisligil, G. S. (2006). Inflammation and metabolic disorders. Nature $444,860-867$.

Hutley, L. J., Herington, A. C. Shurety, W., Cheung, C., Vesey, D. A., Cameron, D. P., and Prins, J. B. (2001). Human adipose tissue endothelial cells promote preadipocyte proliferation. Am. J. Physiol. Endocrinol. Metab. 281, E1037-E1044.

Ide, J., Gagnon, A., Molgat, A. S. D., Landry, A., Foster, C., and Sorisky, A. (2011). Macrophage-conditioned medium inhibits the activation of cyclin-dependent kinase 2 by adipogenic inducers in 3T3-L1 preadipocytes. J. Cell. Physiol. 226, 2297-2306 
Kennedy, D. J., Kuchibhotla, S., Westfall, K. M., Silverstein, R. L., Morton, R. E., and Febbraio, M. (2011). A CD36-dependent pathway enhances macrophage and adipose tissue inflammation and impairs insulin signalling. Cardiovasc. Res. 89, 604-613.

Keophiphath, M., Achard, V., Henegar, C., Rouault, C., Clément, K., and Lacasa, D. (2009). Macrophage-secreted factors promote a profibrotic phenotype in human preadipocytes. Mol. Endocrinol. 23, 11-24.

Keuper, M., Blüher, M., Schön, M. R., Möller, P., Dzyakanchuk, A., Amrein, K., Debatin, K.-M., Wabitsch, M., and Fischer-Posovszky, P. (2011). An inflammatory micro-environment promotes human adipocyte apoptosis. Mol. Cell. Endocrinol. 339, 105-113.

Kintscher, U., Hartge, M., Hess, K., Foryst-Ludwig, A., Clemenz, M., Wabitsch, M., Fischer-Posovszky, P., Barth, T. F., Dragun, D., Skurk, T., Hauner, H., Blüher, M., Unger, T., Wolf, A. M., Knippschild, U., Hombach, V., and Marx, N. (2008). T-lymphocyte infiltration in visceral adipose tissue: a primary event in adipose tissue inflammation and the development of obesitymediated insulin resistance. Arterioscler. Thromb. Vasc. Biol. 28, 1304-1310.

Lacasa, D., Taleb, S., Keophiphath, M., Miranville, A., and Clement, K. (2007). Macrophage-secreted factors impair human adipogenesis: involvement of proinflammatory state in preadipocytes. Endocrinology 148, 868-877.

Lu, C., Kumar, P. A., Fan, Y., Sperling, M. A., and Menon, R. K. (2010). A novel effect of growth hormone on macrophage modulates macrophage-dependent adipocyte differentiation. Endocrinology 151, 2189-2199.

Lumeng, C. N., Deyoung, S. M., Bodzin, J. L., and Saltiel, A. R. (2007a). Increased inflammatory properties of adipose tissue macrophages recruited during diet-induced obesity. Diabetes 56, 16-23.

Lumeng, C. N., Deyoung, S. M., and Saltiel, A. R. (2007b). Macrophages block insulin action in adipocytes by altering expression of signaling and glucose transport proteins. Am. J. Physiol. Endocrinol. Metab. 292, E166-E174.

Magun, R., Boone, D. L., Tsang, B. K., and Sorisky, A. (1998). The effect of adipocyte differentiation on the capacity of 3T3-L1 cells to undergo apoptosis in response to growth factor deprivation. Int. J. Obes. Relat. Metab. Disord. 22, 567-571.

Mestas, J., and Hughes, C. C. W. (2004). Of mice and not men: differences between mouse and human immunology. J. Immunol. 172, 2731-2738.

Miranville, A., Herling, A. W., BiemerDaub, G., and Voss, M. D. (2010). Reversal of inflammation-induced impairment of glucose uptake in adipocytes by direct effect of CB1 antagonism on adipose tissue macrophages. Obesity (Silver Spring) 18, 2247-2254.

Molgat, A. S., Gagnon, A., and Sorisky, A. (2009). Preadipocyte apoptosis is prevented by macrophageconditioned medium in a PDGFdependent manner. Am. J. Physiol. Cell Physiol. 296, C757-C765.

Molgat, A. S. D., Gagnon, A., and Sorisky, A. (2011). Macrophageinduced preadipocyte survival depends on signaling through Akt, ERK1/2, and reactive oxygen species. Exp. Cell Res. 317, 521-530.

Nishimura, S., Manabe, I., Nagasaki, M., Eto, K., Yamashita, H., Ohsugi, M., Otsu, M., Hara, K., Ueki, K. Sugiura, S., Yoshimura, K., Kadowaki, T., and Nagai, R. (2009). CD8+ effector T cells contribute to macrophage recruitment and adipose tissue inflammation in obesity. Nat. Med. 15, 914-920.

O’Hara, A., Lim, F.-L., Mazzatti, D. J., and Trayhurn, P. (2009). Microarray analysis identifies matrix metalloproteinases (MMPs) as key genes whose expression is up-regulated in human adipocytes by macrophageconditioned medium. Pflugers Arch. 458, 1103-1114.

Overman, A., Bumrungpert, A., Kennedy, A., Martinez, K., Chuang, C.-C., West, T., Dawson, B., Jia, W., and McIntosh, M. (2010). Polyphenol-rich grape powder extract (GPE) attenuates inflammation in human macrophages and in human adipocytes exposed to macrophage-conditioned media. Int. J. Obes. (Lond.) 34, 800-808.

Ozcan, U., Cao, Q., Yilmaz, E., Lee, A.H., Iwakoshi, N. N., Ozdelen, E., Tuncman, G., Görgün, C., Glimcher, L. H., and Hotamisligil, G. S. (2004). Endoplasmic reticulum stress links obesity, insulin action, and type 2 diabetes. Science 306, 457-461.

Pekala, P., Kawakami, M., Vine, W., Lane, M. D., and Cerami, A. (1983). Studies of insulin resistance in adipocytes induced by macrophage mediator. $J$. Exp. Med. 157, 1360-1365.
Permana, P. A., Menge, C., and Reaven, P. D. (2006). Macrophagesecreted factors induce adipocyte inflammation and insulin resistance. Biochem. Biophys. Res. Commun. 341, 507-514.

Permana, P. A., Zhang, W., Wabitsch, M., Fischer-Posovszky, P., Duckworth, W. C., and Reaven, P. D. (2009). Pioglitazone reduces inflammatory responses of human adipocytes to factors secreted by monocytes/macrophages. Am. J. Physiol. Endocrinol. Metab. 296, E1076E1084.

Sakurai, T., Kitadate, K., Nishioka, H., Fujii, H., Kizaki, T., Kondoh, Y., Izawa, T., Ishida, H., Radák, Z., and Ohno, H. (2010). Oligomerized grape seed polyphenols attenuate inflammatory changes due to antioxidative properties in coculture of adipocytes and macrophages. J. Nutr. Biochem. 21, 47-54.

Samuvel, D. J., Sundararaj, K. P., Li, Y., Lopes-Virella, M. F., and Huang, Y. (2010). Adipocyte-mononuclear cell interaction, Toll-like receptor 4 activation, and high glucose synergistically up-regulate osteopontin expression via an interleukin 6mediated mechanism. J. Biol. Chem. 285, 3916-3927.

Schneemann, M., and Schoedon, G. (2002). Species differences in macrophage NO production are important. Nat. Immunol. 3, 102.

Shoelson, S. E., Lee, J., and Goldfine, A. B. (2006). Inflammation and insulin resistance. J. Clin. Invest. 116, 1793-1801.

Skurk, T., Alberti-Huber, C., Herder, C., and Hauner, H. (2007). Relationship between adipocyte size and adipokine expression and secretion. J. Clin. Endocrinol. Metab. 92, 1023-1033.

Solinas, G., Vilcu, C., Neels, J. G., Bandyopadhyay, G. K., Luo, J.-L., Naugler, W., Grivennikov, S., WynshawBoris, A., Scadeng, M., Olefsky, J. M., and Karin, M. (2007). JNK1 in hematopoietically derived cells contributes to diet-induced inflammation and insulin resistance without affecting obesity. Cell Metab. 6, 386-397.

Steinberg, H. O., Chaker, H., Leaming, R., Johnson, A., Brechtel, G., and Baron, A. D. (1996). Obesity/insulin resistance is associated with endothelial dysfunction. Implications for the syndrome of insulin resistance. J. Clin. Invest. 97, 2601-2610.

Suganami, T., Mieda, T., Itoh, M., Shimoda, Y., Kamei, Y., and Ogawa,
Y. (2007a). Attenuation of obesityinduced adipose tissue inflammation in $\mathrm{C} 3 \mathrm{H} / \mathrm{HeJ}$ mice carrying a Toll-like receptor 4 mutation. Biochem. Biophys. Res. Commun. 354, 45-49.

Suganami, T., Tanimoto-Koyama, K., Nishida, J., Itoh, M., Yuan, X., Mizuarai, S., Kotani, H., Yamaoka, S., Miyake, K., Aoe, S., Kamei, Y., and Ogawa, Y. (2007b). Role of the Tolllike receptor 4/NF-kappaB pathway in saturated fatty acid-induced inflammatory changes in the interaction between adipocytes and macrophages. Arterioscler. Thromb. Vasc. Biol. 27, 84-91.

Tanaka, H., Nakamura, S., Onda, K., Tazaki, T., and Hirano, T. (2009). Sofalcone, an anti-ulcer chalcone derivative, suppresses inflammatory crosstalk between macrophages and adipocytes and adipocyte differentiation: implication of heme-oxygenase-1 induction. Biochem. Biophys. Res. Commun. 381, 566-571.

Toyoda, T., Kamei, Y., Kato, H., Sugita, S., Takeya, M., Suganami, T., and Ogawa, Y. (2008). Effect of peroxisome proliferator-activated receptor-alpha ligands in the interaction between adipocytes and macrophages in obese adipose tissue. Obesity (Silver Spring) 16, 1199-1207.

Trayhurn, P., and Wood, I. S. (2004). Adipokines: inflammation and the pleiotropic role of white adipose tissue. Br. J. Nutr. 92, 347-355.

Tsuchiya, S., Kobayashi, Y., Goto, Y., Okumura, H., Nakae, S., Konno, T., and Tada, K. (1982). Induction of maturation in cultured human monocytic leukemia cells by a phorbol diester. Cancer Res. 42, 1530-1536.

Tsuchiya, S., Yamabe, M., Yamaguchi, Y., Kobayashi, Y., Konno, T., and Tada, K. (1980). Establishment and characterization of a human acute monocytic leukemia cell line (THP1). Int. J. Cancer 26, 171-176.

Unoki, H., Bujo, H., Jiang, M., Kawamura, T., Murakami, K., and Saito, Y. (2008). Macrophages regulate tumor necrosis factor-alpha expression in adipocytes through the secretion of matrix metalloproteinase-3. Int. J. Obes. (Lond.) 32, 902-911.

Wabitsch, M., Brenner, R. E., Melzner, I., Braun, M., Moller, P., Heinze, E., Debatin, K. M., and Hauner, H. (2001). Characterization of a human preadipocyte cell strain with high capacity for adipose differentiation. Int. J. Obes. Relat. Metab. Disord. 25, 8-15. 
Weisberg, S. P., McCann, D., Desai, M., Rosenbaum, M., Leibel, R. L., and Ferrante, A. W. (2003). Obesity is associated with macrophage accumulation in adipose tissue. J. Clin. Invest. 112, 1796-1808.

Wentworth, J. M., Naselli, G., Brown, W. A., Doyle, L., Phipson, B., Smyth, G. K., Wabitsch, M., O’Brien, P. E., and Harrison, L. C. (2010). Proinflammatory CD11c+ CD206+ adipose tissue macrophages are associated with insulin resistance in human obesity. Diabetes 59, 1648-1656.

Williams, I. L., Chowienczyk, P. J., Wheatcroft, S. B., Patel, A. G., Sherwood, R. A., Momin, A., Shah, A. M., and Kearney, M. T. (2005). Endothelial function and weight loss in obese humans. Obes. Surg. 15, 1055-1060.

Winer, S., Chan, Y., Paltser, G., Truong, D., Tsui, H., Bahrami, J., Dorfman, R., Wang, Y., Zielenski, J., Mastronardi, F., Maezawa, Y., Drucker, D. J., Engleman, E., Winer, D., and Dosch, H. M. (2009). Normalization of obesity-associated insulin resistance through immunotherapy. Nat. Med. 15, 921-929.

Wood, I. S., de Heredia, F. P., Wang, B., and Trayhurn, P. (2009). Cellular hypoxia and adipose tissue dysfunction in obesity. Proc. Nutr. Soc. 68, 370-377.
Wu, H., Ghosh, S., Perrard, X. D., Feng, L., Garcia, G. E., Perrard, J. L., Sweeney, J. F., Peterson, L. E., Chan, L., Smith, C. W., and Ballantyne, C. M. (2007). T-cell accumulation and regulated on activation, normal $\mathrm{T}$ cell expressed and secreted upregulation in adipose tissue in obesity. Circulation 115, 1029-1038.

Xiao, L., Aoshima, H., Saitoh, Y., and Miwa, N. (2010). The effect of squalane-dissolved fullerene-C60 on adipogenesisaccompanied oxidative stress and macrophage activation in a preadipocyte-monocyte co-culture system. Biomaterials 31, 5976-5985.

Xie, L., Ortega, M. T., Mora, S., and Chapes, S. K. (2010). Interactive changes between macrophages and adipocytes. Clin. Vaccine Immunol. 17, 651-659.

Xu, H., Barnes, G. T., Yang, Q., Tan, G., Yang, D., Chou, C. J., Sole, J., Nichols, A., Ross, J. S., Tartaglia, L. A., and Chen, H. (2003). Chronic inflammation in fat plays a crucial role in the development of obesity-related insulin resistance. J. Clin. Invest. 112, 1821-1830.

Yarmo, M. N., Gagnon, A., and Sorisky, A. (2010). The anti-adipogenic effect of macrophage-conditioned medium requires the IKK $\beta / N F-\kappa B$ pathway. Horm. Metab. Res. 42, 831-836.
Yarmo, M. N., Landry, A., Molgat, A. S. D., Gagnon, A., and Sorisky, A. (2009). Macrophage-conditioned medium inhibits differentiationinduced Rb phosphorylation in 3T3L1 preadipocytes. Exp. Cell Res. 315 , 411-418.

Yeop Han, C., Kargi, A. Y., Omer, M. Chan, C. K., Wabitsch, M., O’Brien, K. D., Wight, T. N., and Chait, A. (2010). Differential effect of saturated and unsaturated free fatty acids on the generation of monocyte adhesion and chemotactic factors by adipocytes: dissociation of adipocyte hypertrophy from inflammation. Diabetes 59, 386-396.

Yuan, M., Konstantopoulos, N., Lee, J., Hansen, L., Li, Z. W., Karin, M. and Shoelson, S. E. (2001). Reversal of obesity- and diet-induced insulin resistance with salicylates or targeted disruption of Ikkbeta. Science 293 1673-1677.

Zhang, X., Laubach, V. E., Alley, E. W., Edwards, K. A., Sherman, P. A., Russell, S. W., and Murphy, W. J. (1996). Transcriptional basis for hyporesponsiveness of the human inducible nitric oxide synthase gene to lipopolysaccharide/interferongamma. J. Leukoc. Biol. 59, 575-585.

Conflict of Interest Statement: Michaela Keuper and Pamela Fischer-
Posovszky declare that the research was conducted in the absence of any commercial or financial relationships that could be construed as a potential conflict of interest. Anna Dzyakanchuk and Kurt E. Amrein are employed at pERD, F. Hoffmann-LaRoche Ltd., Basel, Switzerland. Martin Wabitsch has worked as a consultant of F. HoffmannLaRoche Ltd. and received a consultant fee.

Received: 25 August 2011; paper pending published: 20 September 2011; accepted: 15 November 2011; published online: 14 December 2011.

Citation: Keuper M, Dzyakanchuk A, Amrein KE, Wabitsch $M$ and FischerPosovszky P (2011) THP-1 macrophages and SGBS adipocytes - a new human in vitro model system of inflamed adipose tissue. Front. Endocrin. 2:89. doi: 10.3389/fendo.2011.00089

This article was submitted to Frontiers in Systems and Translational Endocrinology, a specialty of Frontiers in Endocrinology.

Copyright (C) 2011 Keuper, Dzyakanchuk, Amrein, Wabitsch and FischerPosovszky. This is an open-access article distributed under the terms of the Creative Commons Attribution Non Commercial License, which permits noncommercial use, distribution, and reproduction in other forums, provided the original authors and source are credited. 